\title{
An Experimental Study of Double-Income Personal Taxpayers: The Role of Tax Reporting Facilities and Love of Money Attitude
}

\author{
Etik Kresnawati ${ }^{1, *}$ Dela Delfia Sari ${ }^{1}$ Andan Yunianto ${ }^{1}$ \\ ${ }^{1}$ Universitas Muhammadiyah Yogyakarta, Indonesia \\ "Corresponding author. Email: etikkresnawati@umy.ac.id
}

\begin{abstract}
This study aims to examine the effect of the tax reporting facility on double-income personal taxpayers' compliance moderated by the love of money attitude. Quasi- experimental design methods ( $2 \times 2$ between subjects) were used for32 undergraduate students as surrogate participants. For tax calculation and reporting, personal taxpayers who had double income were employed, namely income from the permanent employment (fixed income) and independent personal service (free income). Experiments were carried out through online media utilizing modified e-filing software. The test results using two-way ANOVA revealed that the interaction between reporting facility and the love of money attitude affected tax compliance of double- income personal taxpayers, while the main effect was not shown. The implication is that regulators should consider requiring employers to facilitate tax reporting for their employees.
\end{abstract}

Keywords: Double-Income Personal Taxpayers, Tax Reporting Facility, Love Of Money Attitude, Tax Compliance.

\section{INTRODUCTION}

According to Law Number 16 of 2009, taxes are mandatory contributions to the state owed by private persons or entities that are compelling under the Law, without receiving direct compensation, and are used for state needs for people's greatest welfare [1]. Taxes are the most dominant source of state revenue in increasing the state treasury [2]. Based on the decision of the Directorate General of Taxes Number Kep-88/PJ/2004, e-filing was established and came into effect in 2004 [3].

E-filing issuance is a form of tax reform. E-filing is a service system for filling and submitting Annual Tax Returns (SPT) electronically through an online system. In their research, Aryati \& Putritanti stated that facilities that make it easier for personal taxpayers (WPOP) in tax reporting would affect compliance [4]. It means, the better the facilities, the more personal taxpayers will comply with their tax obligations. According to Gustiani, taxpayer compliance is the compliance of a taxpayer in registering himself to have a Taxpayer Identification Number (NPWP), SPT calculation, SPT reporting, and tax payments [5]. A taxpayer can be said to interpret and imply taxes properly if he does these four things. Besides, Tahar \& Rachman affirmed that taxpayer compliance was influenced by the WPOP's awareness of their tax obligations, where taxation awareness is an internal factor that comes from within the WPOP [6].

The awareness factor of paying taxes is the basis of attention in this study. It could be that personal taxpayers who do not have the awareness to pay taxes will not want to pay taxes even though the reporting system has been simplified.

Nevertheless, research conducted by Suherman et al. disclosed that the application of e-filing did not affect taxpayer compliance [2]. It was due to the lack of awareness and understanding of personal taxpayers towards technology. Several previous studies, which have been mentioned, examined the e-filing facilities provided by the Directorate General of Taxes. Unlike previous studies, this study examines the reporting facilities provided by the employer.

The reporting facility in question is a facility provided by the agency to employees by calculating and reporting the annual income tax sourced from the agency through its e-filing. However, because it is not their obligation, not all agencies provide SPT reporting facilities to their employees. In a WPOP that only has one income source, the WPOP will automatically comply with tax 
regulations. However, something different will happen when the WPOP has another source of income, i.e. from independent personal service, whose reporting is not facilitated by the employer. It opens up opportunities for WPOPs not to comply because they do not want to bother making corrections to their annual income. Besides, WPOP may have a high love of money attitude. Love of money is a person's behavior towards money and one's desires and aspirations for money [7]. Thus, the love of money can have an interaction effect on the reporting facilities provided by the employer.

This study's motivation is more focused on the interaction effect between the love of money variable and the reporting facility from the employer on doubleincome personal taxpayers' compliance level, namely ethical behavior. This study is different from previous studies. We used the reporting facility from the employer as independent variable, instead of facilities from regulator and tax service office, which was test on double-income personal taxpayers. This phenomenon is important to examine because individual taxpayers with two sources of income (fixed income and free income) have higher possibility to ignore their tax obligations than individual taxpayers with fixed income only. Besides, we use experimental method to provide better empirical evidence than research with the questionnaire method. With this method, we can observe directly the attitude of WPOP compliance through the treatment of tax reporting facility, love of money attitude, and tax compliance.

\section{LITERATURE REVIEW AND HYPOTHESIS DEVELOPMENT}

\section{Attribution Theory}

Attribution theory is proposed to develop explanations for the different ways of assessing individuals. When observing an individual's behavior, there is an attempt to determine whether the behavior is caused internally or externally [8].

\section{Theory of Planned Behavior (TPB)}

Theory of Planned Behavior, which was initiated by [9], is a development of the Theory of Reasoned Action (TRA), where a person's behavior is caused by his intentions. Theory of planned behavior (TPB) is behavior that appears in an individual because the individual has the intention to behave, and the behavior is caused by several factors such as behavioral beliefs, normative beliefs, and control beliefs

\section{The Influence of Love of Money Attitude on Double-Income Taxpayer Compliance}

In taxation, reporting facilities are facilities provided to facilitate tax reporting for individual taxpayers and corporate taxpayers. Tax Directorate General has facilitated the calculation and reporting of taxpayers in the form of e-filing, e-SPT, and e-registration software since 2014. In addition to the facilities provided by the TDG, several institutions in Indonesia also provide annual tax returns reporing services for their employees'. As implied in the TPB, reporting facilities, both provided by the DGT and the employer, are thought to increase WPOP reporting compliance.

Several studies examining WPOP compliance related to the application of e-SPT [10], e-filing [11], and [12] suggest that this reporting facility from the DGT improves WPOP compliance. However, [6] suggest that tax employee service facilities has not boosted WPOP satisfaction. In contrast to the two research groups, this study examines the income tax reporting service facilities provided by the employer. Theoretically, WPOP with this facility will have a higher level of compliance when compared to WPOP who report independently. However, for WPOPs that have multiple sources of income, namely permanent income from the employer and free income, they must revise their tax report to include free income. Reporting facility from the employer will relieve the task of WPOP with double income in reporting their all income in the e-filing system.

H1: Tax reporting facilities from employer have a positive effect on double income taxpayer compliance.

\section{The Influence of Love of Money Attitude Toward Double-Income WPOP Compliance}

Love of money is a person's desire and aspiration for money [7]. The higher one's love of money attitude, the higher the possibility for someone to commit unethical actions. The attitude of love of money is an internal factor originating from the WPOP which is thought to influence them in carrying out their tax obligations.

In their research, [13] and [14] show that the love of money attitude of WPOP makes them behave unethically in the form of tax evasion. These results reinforce the argument that love of money can cause someone to take negative or unethical actions [15], including in the field of taxation. For double income taxpayers, the possibility of this unethical behavior is expected to be even greater because there is a part of income that may not be detected by the tax office, unless reported by the WPOP.

H2: The attitude of Love of Money has a negative effect on double income taxpayer compliance.

\section{Moderation Effect of Love of Money on the Relationship between Reporting Facilities and Double-Income Taxpayer Compliance}

Individual taxpayers with two sources of income must report taxes on both their income. When reporting his tax, an individual taxpayer must combine the two sources of income he gets. Thus, individual taxpayers will receive one withholding proof of their tax reporting. If an individual taxpayer does not report one of his incomes, 
the individual taxpayer can be said to be non-compliant with his tax obligations. The ease of reporting provided by employers is thought to increase tax compliance with double-income WPOPs because they only need to include their free source of income in their SPT reporting. However, this compliance will be influenced by their love of money attitude because there is an opportunity for double-income WPOPs to not report their free income.

H3: There is an interaction between reporting facilities and the love of money attitude towards double income taxpayer compliance.

\section{RESEARCH METHOD}

Subjects in this study were double-income personal taxpayers, represented by accounting students from the Faculty of Business Economics, Universitas Muhammadiyah Yogyakarta. The sampling technique in this study used a probability sampling method in the form of a simple random sampling technique. This research type is a quasi-experimental design. The data collection process employed $2 \times 2$ between subject design model. The experiment was carried out at the Universitas Muhammadiyah Yogyakarta. In completion, this study required duration of 45 minutes. With the implementation of a lockdown system by the University due to COVID-19, this experimental research was conducted through online media.

\section{Independent Variable}

The independent variable in this study was the reporting facility. The reporting facility is a service provided by the employer. Reporting facilities were measured by applying different treatments in working on experimental case questions. In the case of experimental questions, this study's participants were divided into two groups: those who received reporting facilities and those who did not.

\section{Moderation Variable}

The moderating variable in this study was the love of money. According to Luna-Arocas \& Tang, love of money is a person's behavior towards money and one's desires and aspirations for money [7]. The love of money attitude in this study was evaluated by asking one question that required participants to choose between spending their money or not at all. Besides, the love of money attitude was also measured by looking at the free income reported by personal taxpayers.

\section{Dependent Variable}

The dependent variable in this study was personal taxpayer compliance. Compliance in paying taxes is the responsibility of the people and the government to God, who has their respective rights and obligations [6]. Personal taxpayer compliance was assessed using an indicator of whether the WPOPs made payments and reported income from their independent business.

\section{RESEARCH RESULTS AND DISCUSSION}

This study's objects were undergraduate students of Accounting Department, Faculty of Economics and Business, Universitas Muhammadiyah Yogyakarta, with a total of 78 applicants. However, some participants were not willing as many as 36 people so that only 42 people were willing. Of the 42 people, only 32 passed the manipulations check test. Thus, the participants in this study were 32 people.

\section{Descriptive Statistical Analysis}

Table 1. Descriptive Statistical Test Result Of The Research Variables

\begin{tabular}{|l|c|c|c|c|}
\hline Facilities & LoM & Mean & Std. Deviation & N \\
\hline \multirow{2}{*}{ NO } & Low & .7580 & .18075 & 5 \\
& High & .9400 & .10276 & 11 \\
& Total & .8831 & .15278 & 16 \\
\hline YES & Low & .8350 & .13148 & 8 \\
& High & .7525 & .14099 & 8 \\
& Total & .7938 & .13841 & 16 \\
\hline Total & Low & .8054 & .14998 & 13 \\
& High & .8611 & .15048 & 19 \\
& Total & .8384 & .15042 & 32 \\
\hline
\end{tabular}

Source: Data processed, 2020

The table above shows the number of participants who participated in the tax reporting simulation using efiling. The table shows that 16 participants did not receive reporting facilities with a mean value of 0.8831 and a standard deviation of 0.15278 . Participants who did not receive reporting facilities with a low love of money level were five people, with a mean value of 0.7580 and a standard deviation of 0.18075 .

Meanwhile, 11 participants did not receive the reporting facility with a high love of money level, with an average value of 0.9400 and a standard deviation of 0.10276. It denoted an increase in the mean value of participants with a high love of money level from participants with a low love of money level by 0.182 . Thus, participants who had a high love of money attitude were more than participants who had low love of money.

Moreover, participants who received reporting facilities were 16 people, with a mean value of 0.7938 and a standard deviation of 0.13841 . There were 8 participants with a low love of money level, with a mean value of 0.8350 and a standard deviation of 0.13148 . There were 8 participants with a high love of money level, with a mean value of 0.7525 and a standard deviation of 0.14099 . There is no difference between 
participants with a high love of money level and participants with a low love of money level. In this variable, there was no significant difference in the mean value so that it could be seen that the reporting facility has not been able to increase personal taxpayer compliance.

\section{Normality Test And Homogeneity Test}

In the testing analysis of variance, the first step before testing the hypothesis was to test the homogeneity of variance using the Levine's test and the assumption of normality using the One-Sample Kolmogorov Smirnov Test.

Table 2. Normality Test Results

\begin{tabular}{|c|l|}
\hline Explanation & $\begin{array}{l}\text { One-Sample Kolmogorov Smirnov } \\
\text { Test }\end{array}$ \\
\hline Compliance & .134 \\
\hline
\end{tabular}

Source: Data processed, 2020

Table 3. Homogenity Test Result

\begin{tabular}{|l|l|l|}
\hline \multirow{2}{*}{ Explanation } & \multicolumn{2}{|c|}{ Levine's Test } \\
\cline { 2 - 3 } & $\mathrm{F}$ & Sig \\
\hline Compliance & 1.425 & .256 \\
\hline
\end{tabular}

Source: Data processed, 2020

The test results revealed that the value of Levine's test was .256. Thus, it could be concluded that the data variant was homogeneous because the value was higher than 0.05 . Meanwhile, the normality test results exposed that the One- Sample Kolmogorov Smirnov Test value was .134. Thus, it could be concluded that this study's data demonstrated a normal data variant because it had a value higher than 0.05 . Therefore, this study's data were normally distributed and homogeneous, meaning that it could be tested using ANOVA.

\section{Hypothesis 1 (H1) Testing}

This test would explain whether there was a difference in the compliance level between personal taxpayers whose reporting was facilitated and reporting was not facilitated. Personal taxpayers who did not receive reporting facilities were used as a control group to determine whether the reporting facilities provided by the employer could affect personal taxpayer compliance.

Table 4. Hypothesis Test Results Of Reporting Facilities

\begin{tabular}{|l|l|l|l|}
\hline Explanation & Df & F & Sig. \\
\hline $\begin{array}{l}\text { Reporting } \\
\text { Facility }\end{array}$ & 1 & 1.273 & .269 \\
\hline $\begin{array}{l}\text { Adjusted R } \\
\text { Square }\end{array}$ & .216 & \\
\hline
\end{tabular}

Source: Data processed, 2020
The first test was performed to see whether there was an influence between the reporting facilities on personal taxpayer compliance. This test predicted that the reporting facility by the employer could improve personal taxpayer compliance. The table above shows a determination coefficient of 0.216 . It suggested that the reporting facility variable could explain the personal taxpayer compliance variable by $21.6 \%$, while $78.4 \%$ was explained by other variables not examined in this study. The level of significance used in this study was 0.05 . It could be seen in the table that the significance value of the first hypothesis was 0.269 . Thus, the first hypothesis was rejected. This research is in line with previous research Sari [16].

\section{Hypothesis 2 (H2) Testing}

This test would explain whether the personal taxpayers' love of money level could affect their compliance with tax regulations.

Table 5. Love Of Money Hypothesis Test Result

\begin{tabular}{|l|l|l|l|}
\hline Explanation & Df & F & Sig. \\
\hline Love of money & 1 & 1.032 & 0.318 \\
\hline $\begin{array}{l}\text { Adjusted R } \\
\text { Square }\end{array}$ & .216 & \\
\hline
\end{tabular}

Source: Data processed, 2020

The second test was conducted to see whether there was an influence between the love of money on personal taxpayer compliance. This test predicted that the love of money level could affect personal taxpayer compliance. The table above presents a determination coefficient of 0.216 . It indicated that the love of money variable could explain the personal taxpayer compliance variable by $21.6 \%$, while $78.4 \%$ was explained by other variables not examined in this study. The level of significance employed in this study was 0.05 . It could be seen in the table that the significance value of the second hypothesis was 0.318 . Thus, the second hypothesis was rejected. This research is in line with the research of Sofha \& Machmuddah [17].

\section{Hypothesis 3 (H3) Testing}

This test would explain whether personal taxpayers' love of money could interact with the reporting facilities by the employer, thereby reducing their compliance with tax regulations.

Table 5. Interaction Hypothesis Test Results Of Facilities *Love Of Monet

\begin{tabular}{|l|l|l|l|}
\hline Explanation & Df & F & Sig. \\
\hline $\begin{array}{l}\text { Facility*Love of } \\
\text { Money }\end{array}$ & 1 & 7.295 & .012 \\
\hline \multicolumn{2}{|l}{ Adjusted R square } & .216 \\
\hline
\end{tabular}

Source: Data processed, 2020 
The third test was carried out to see whether there was an interaction effect of the love of money on the reporting facility of personal taxpayer compliance. This test predicted that the love of money level could affect the reporting facilities, which would have implications for personal taxpayer compliance. The table above reveals a determination coefficient of 0.216 . It implied that the love of money variable could explain the facilities and compliance variables of personal taxpayers by $21.6 \%$, while $78.4 \%$ was explained by other variables not examined in this study. The level of significance utilized in this study was 0.05 . It could be seen in the table that the significance value of the third hypothesis was 0.012 . Therefore, the third hypothesis was accepted. This research is in line with [18], [15], and [13].

\section{CONCLUSION}

Tax reporting facilities originating from the employer could not affect double-income personal taxpayer compliance. It was because tax reporting on independent business was not facilitated so that personal taxpayers still had to report independently.

The love of money attitude did not affect personal taxpayer compliance. Several factors might arise; for example, they did not want to bother going back to the next step to remove their income, and participants continued the payment process. Another factor was that the participants less felt the expected outcome in reality.

The love of money attitude had an interaction effect with the reporting facility by the employer on the doubleincome personal taxpayer compliance. The high taxpayer's love of money attitude could affect the employer's reporting facilities so that personal taxpayer compliance level was low.

\section{LIMITATIONS}

The minimum number of samples was deemed less representative of the WPOP. Although it could be tested, a larger sample size could give a better picture.

The initially designed research to be carried out in the classroom was canceled due to a campus policy regarding restrictions on lecture activities (lockdown). Thus, the experiment was performed through online media. It impacted conduciveness in conducting experiments.

Concerning the experimental method via online media, the researchers could not control the variables tested in this study.

Determination of the WPOP's love of money level was not precise, so that the love of money measurement was not strong enough. Thus, hypothesis 2 was not supported because the love of money measure was less precise.
The uncontrolled use of students as a surrogate could directly influence the research results.

\section{RECOMMENDATIONS}

The next researchers can examine the effect of love of money attitudes and reporting facilities by employers and add variables affecting personal taxpayer compliance, such as religiosity.

The next researcher is to continue the research by conducting direct experiments and using real subjects so that the data obtained is in accordance with personal taxpayers' actual characteristics.

The next researcher can design and prepare better experiments in unexpected situations.

\section{REFERENCES}

[1] Undang-Undang Republik Indonesia, UndangUndang Republik Indonesia Nomor 16 Tahun 2009.

[2] M. Suherman, A. Medina, and R. Marliana, "Pengaruh Penerapan E-Filing Terhadap Kepatuhan Wajib Pajak Dalam Penyampaian Surat Pemberitahuan (Spt) Tahunan Pada Kantor Pelayanan Pajak Pratama Kota Tasikmalaya," Media Ris. Akunt., vol. 15, pp. 49-64, 2015.

[3] Keputusan Direktur Jendral Pajak Nomor Kep88/PJ/2004. 2004.

[4] T. Aryati and L. R. Putritanti, "Pengaruh Pemanfaatan Teknologi Dan Modernisasi Sistem Administrasi Perpajakan Terhadap Kepatuhan Wajib Pajak Orang Pribadi," J. Ris. Akunt. dan Keuang., vol. 4, no. 3, pp. 1155-1168, 2016, doi: 10.17509/jrak.v4i3.4669.

[5] A. Gustiani, "Pengaruh Penerapan E-SPT Dan Pengetahuan Perpajaan Terhadap Kepatuhan Wajib Pajak (Survey Pada Kantor Pelayanan Pajak Pratama Karees Bandung)," 2014.

[6] A. Tahar and A. K. Rachman, "Pengaruh Faktor Internal dan Faktor Eksternal Terhadap Kepatuhan Wajib Pajak," J. Akunt. dan Investasi, vol. 15, no. 1, pp. 56-67, 2014.

[7] R. Luna-Arocas and T. L. P. Tang, "Are You Satisfied With Your Pay When You Compare? It Depends on Your Love of Money, Pay Comparison Standards, and Culture," J. Bus. Ethics, 2014, doi: 10.1007/s10551-014-2100-4.

[8] R. Stephen P and J. Timothy A, Perilau Organisasi, Edisi Kedu. Jakarta: Salemba Empat, 2008. 
[9] I. Ajzen, "From Intentions to Actions: A Theory of Planned Behavior," Action Control, 1985, doi: 10.1007/978-3-642-69746-3_2.

[10] F. A. Zuhdi, Topowijono, and D. F. Azizah, "Pengaruh Penerapan E-SPT dan Pengetahuan Perpajakan Terhadap Kepatuhan Wajib Pajak (Studi Pada Pengusaha Kena Pajak Yang Terdaftar Di KPP Pratama Singosari)," J. Perpajak., vol. 7, no. 1, pp. 193-206, 2015.

[11] T. Gunawan, E. Suprapti, and E. T. Kurniawati, "Presepsi Wajib Pajak Mengenai E-Filing Dan Pengaruhnya Terhadap Tingkat Kepatuhan Wajib Pajak Orang Pribadi Dalam Melaporkan Pajak," J. Reviu Akunt. dan Keuang., vol. 4, no. 2, pp. 615622, 2014.

[12] A. K. Tumuli, J. J. Sondakh, and H. R. . Wokas, "Analisis Penerapan E-Spt Dan E-filling Dalam Upaya Peningkatan Kepatuhan Wajib Pajak," $J$. EMBA ISSN 2302-1174, vol. 4, no. 3, pp. 102-112, 2016.

[13] T. L. Tang and R. K. Chiu, "Income, Money Ethic, Pay Satisfaction, Commitment, and Unethical Behavior: Is The Love Of Money The Root Of Evil For Hong Kong Employees," J. Bus. Ethics, vol. 46, pp. 13-30, 2003.

[14] N. P. S. M. Asih and K. T. Dwiyanti, "E-Jurnal Akuntansi Universitas Udayana Pengaruh Love Of Money, Machiavellian, dan Equity Sensitivity Terhadap Persepsi Etika Penggelapan Pajak ( Tax Evasion ) FakultasaEkonomirdan BisnisaUniversitasaPendidikan Nasionalf ( Undiknas ), Bali , Indonesia AB,' vol. 26, pp. 14121435, 2019.

[15] T. L. P. Tang et al., "The love of money is the root of all evil: Pay satisfaction and cpi as moderators," Acad. Manag. 2011 Annu. Meet. - West Meets East Enlightening. Balanc. Transcending, AOM 2011, no. January, 2011.

[16] M. A. Sari, "Faktor-Faktor Yang Mempengaruhi Kemauan Membayar Pajak Bagi Wajib Pajak Pribadi Yang Melakukan Pekerjaan Bebas Dalam Perspektif Ekonomi Islam (Studi Kasus Di Kantor Pelayanan Pajak Pratama Kedaton),” 2017.

[17] D. Sofha and Z. Machmuddah, "Persepsi Etika Penggelapan Pajak: Pengaruh Langsung dan Tidak Langsung," J. Ilmu Akunt., vol. 12, no. 1, pp. 65-82, 2019, doi: 10.15408/akt.v12i1.12655.

[18] B. Aditya, "Pengaruh Probabilitas Pemeriksaan Pajak dan Sikap Love Of Money Terhadap Kejujuran Pelaporan Wajib Pajak Yang Memiliki
Penghasilan Lebih Dari Satu Pemberi Kerja : Studi Eksperimental," 2019. 